НАРЦИСТИЧНА ОСОБИСТІСТЬ У СУЧАСНОМУ ВИМІРІ

\title{
NARCISTIC PERSONALITY IN THE MODERN DIMENSION
}

УдК 159.942-057,875:005,336,2 DOI https://doi.org/10.32843/26635208.2020.12-2.12

\section{Васильєва Г.В.}

к.психол.н., доцент кафедри психології Чорноморський національний університет імені Петра Могили

\begin{abstract}
У статті розглядається роль нарцистичного френомена в сучасному світі. Розглянуто нарцистичні прояви як ознаки патологічної особистості, вплив сучасного суспільства на формування нарцистичних цінностей. Розкрито роль і місце нарцистичних проявів серед інших психологічних типів особистості, проаналізовано теоретичні основи дослідження й основні концепції розуміння нарцистичних проявів, зв'язок типів психологічних захистів для соціальної адаптації. Визначено критерії паталогічного нарцисизму та психологічного френомена. Автором проведено дослідження із застосуванням нарцистичного опитувальника особистості NPI-40 для діагностики рівня нарцистичних проявів $і$ діагностики виду нарцистичних проявів. Метою дослідження $є$ психологічна структура та прояви феномена нарцисизму в сучасній психологічній практиці. Автор розглядає алекситимію як один із фракторів, що пов'язаний із рівнем проявів нарцистичних рис особистості, як психологічний френомен, що пов'язаний із таким особистіснім параметром, як емоційна зрілість. Це здатність людини диференціювати власні емоційні реакції, почуття, бути чутливим до емомій інших людей. Важливість успіху, постійна потреба в досягненнях, конкуренції, потреба в визнанні та успішності, зростання потреб у споживанні - виклики сучасності. Ці дуже буденні та знайомі нам прояви сучасного життя, багатьма нами сприймаються як нормальні та звичайні, вони оточують нас і фрормують світогляд і внутрішній психологічний простір. Автором розглянуто різні підходи до визначення нарцисизму в сучасній науці. Так, позначають нарцистичну особистість, тобто людину з нарцистичним радикалом, яка характеризується певним набором психологічних захистів і поведінкових проявів. Ці прояви можуть бути патологічними, тобто порушувати соціальну адаптацію, і непатологічними.

Ключові слова: нарцисизм, психологічні захисти, емоційна зрілість, алекситимія, емоційна компетентність.
\end{abstract}

The article present the role of the narcissistic phenomenon in the modern society. Narcissistic demonstrations reviewed both as a sign of pathological personality and as the result of modern society influence on the formation of narcissistic values. The role and place of narcissistic manifestations among other psychological types of personality are revealed. Theoretical bases of research and basic concepts of understanding of narcissistic manifestations, connection of types of psychological protections for social adaptation are analyzed. The criteria of pathological narcissism and psychological phenomenon were determined. The author conducted a study using a narcissistic questionnaire for the NPI-40 personality to diagnose the level of narcissistic manifestations and to diagnose the type of narcissistic manifestations. The purpose of the study is the psychological structure and manifestations of the phenomenon of narcissism in modern psychological practice. The author considers alexithymia as one of the factors associated with the level of manifestation of narcissistic personality traits, as a psychological phenomenon, which is related to such a personal parameter as emotional maturity. It is the ability of a person to differentiate their emotional reactions, feelings, and to be sensitive to other people's emotions. The importance of success, the constant need for achievement, competition, the need for recognition and success the growing need for consumption are the challenges of today. These are very ordinary and familiar to us characteristics of modern life, many of us are perceived themas normal and ordinary, they surround us and shape our background and innerpsychological space. The author reviews different approaches to the definition of narcissism in modern science. In such way a narcissistic personalityis identifying, a person with a narcissistic radical, characterized by a certain set of psychological protections and behavioral manifestations. These manifestations can be pathological, in other words disrupt social adaptation, and non-pathological. Key words: narcissism, psychological protection, emotional maturity, alexithymia, emotional competence.
Постановка проблеми. Нарцисизм як психологічний феномен $€$ досить широким і буденним у сучасному житті. Важливість успіху, постійна потреба в досягненнях, конкуренції, потреба в визнанні та успішності, зростання потреб у споживанні - такі виклики сучасності. Ці дуже буденні та знайомі нам прояви сучасного життя багатьма нами сприймаються як нормальні та звичайні, вони оточують нас і формують світогляд і внутрішній психологічний простір. Але саме вони є руховою силою поширення та розвитку такого психологічного феномена, як нарцисизм. Нарцисизм $€$ психологічною характеристикою особистості, яка має багато визначень. Так, позна- чають нарцистичну особистість, тобто людину з нарцистичним радикалом, яка характеризується певним набором психологічних захистів і поведінкових проявів. Ці прояви можуть бути патологічними, тобто порушувати соціальну адаптацію, і непатологічними. Існують багато класифікацій нарцистичних проявів. Діагностичні критерії нарцисичного розладу особистості представлені в DSM-IV (1994). Для постановки цього розладу характерні необмежена грандіозність і відсутність емпатії. Розлад може діагностуватися за наявності п'яти або більше ознак, серед яких такі: 1) грандіозне почуття власної значущості; 2) захопленість фантазіями необмеженого успіху, влади; 
3) віра у власну унікальність, котру можуть оцінити тільки особливо обдаровані люди; 4) потреба в захопленні; 5) почуття привілейованості; 6) експлуатативність у міжособистісних стосунках; 7) відсутність емпатії; 8) заздрість до успіхів інших; 9) нахабна, зухвала поведінка [1, с. 265].

Постановка завдання. Мета статті - розглянути роль нарцистичного феномена в сучасному світі.

Виклад основного матеріалу дослідження. Диференціація нормального та патологічного нарцисизму є окремою психодіагностичною проблемою, вирішення якої позначається на наданні психологічної, психотерапевтичної допомоги та якості життя. Нарцисичні прагнення й бажання властиві всім людям, вони вважаються нормальними, якщо не набувають провідної ролі в особистісному функціонуванні. Основою нарцистичної особистості $€$ нарцистична довершеність - це та фантазія, заради підтримання якої суб'єкт удається до витіснення, раціоналізації та інших психологічних захистів. Люди захищають ідеальний образ Я від будь-яких переживань його недовершеності. У психоаналізі завжди беруть до уваги нарцисичну природу численних особистісних утворень і характеристик. Патологічний нарцисизм пов'язаний із дефіцитом самоповаги та заниженою самооцінкою. Через надто вимогливе Супер-Его такі люди відчувають себе не просто самотніми й непотрібними, а зовсім не гідними любові та уваги. Вони мають постійну потребу в підтвердженні власної значущості [1, с. 265].

Одним із критеріїв диференціації нормального та патологічного нарцисизму $€$ використання тих чи інших психологічних захистів. Диференційна діагностика нормального й патологічного нарцисизму відбувається за допомогою врахування рівня особистісної організації та власних способів реагування на образу [1, с. 264].

у сучасних наукових дослідженнях тема нарцистичних порушень $€$ досить поширеною [5; 6]. Але не існує єдиної концепції розуміння нарцистичної особистості, її структури та ґенезу. Нарцистичний особистісний розлад тільки в 1980 році включено в DSM-III. У розроблення концепції нарцисизму внесла вклад низка авторів: З. Фрейд, О. Кернберг, Х. Кохут, М. Кляйн та ін. Згідно з DSM-IV [2; 5; 6], нарцисичний особистісний розлад діагностується в разі встановлення п'яти й більше ознак, серед яких виділені:

- грандіозне почуття власної значущості;

- залученість у фантазії про необмежені владу й успіх;

- віра у власну унікальність, оцінити яку можуть тільки обрані, особливо обдаровані люди;
- потреба в захопленні;

- відчуття привілейованості;

- експлуатація інших у міжособистісних відносинах;

- відсутність емпатії;

- заздрість до чужих досягнень;

- нахабна поведінка.

Особистість із нарцистичним радикалом характеризується порушенням у структурі ідентичності. У нормі - ідентичність постійно змінюється, тобто це динамічне функціональне утворення. Динамічність передбачає можливість змін і розвитку. 3 іншого боку, як не парадоксально, ще однією умовою здорової ідентичності є статичність або стабільність. Стабільність дає людині відчуття стійкості Я в часі. І це одна з умов здорової ідентичності - баланс динамічності-статичності. Динамічність-статичність $є$ біполярними модальностями ідентичності. Високий ступінь диференційованості передбачає усвідомлення й виділення багатьох сторін або якостей свого Я (чоловік, професіонал, розумний, наполегливий, чесний тощо). Низький ступінь диференційованості описує полюс дифузності. На когнітивному рівні недиференційована Я-концепція буде проявлятися в тому, що знання людини про себе будуть фрагментарними, уривчастими, суперечливими, на емоційному - у «зараженні» чужими емоціями, відсутності розуміння своїх почуттів і бажань [3, с. 136].

у рамках дослідження нарцисизму як особистісного радикалу нами досліджено та виявлено зв'язок між рівнем алекситимії та рівнем виразності нарцистичних проявів. Так, у групі з високими показниками алекситимії (середні показники - 72,4) показники за шкалою нарцисизму становили 17,4, що визначається як середні бали за шкалою (9-22). У групі з низькими показниками алекситимії середній бал 54,5, показники нарцистичних проявів нижчі 12,88 , але також $є$ в середньому діапазоні [4].

Результати дослідження відображають високий рівень алекситимії у вибірці студентів-психологів. Зіставляючи з нашими даними, ми можемо побачити, що алекситимія за статистикою наявна в 5-25\% здорових людей, а наші результати $(41,6 \%)$ набагато перевищують середній рівень по вибірці, що підтверджує більш високу частоту особистісних та емоційних девіацій у вибірці студентів-психологів. Високий і середній рівні алекситимії поєднуються 3 підвищенням рівня нарцистичних проявів. Також високий рівень алекситимії пов'язаний із загальною напруженістю та корелює переважно з такими захистами, як проекція та регресія, які визначаються як найбільш незрілі. Низький рівень алекситимічних проявів корелює з використанням більш зрілого механізму раціоналізації. Установлено, 
що більш високі показники алекситимічних проявів корелюють із підвищенням рівня нарцистичних проявів у структурі особистості. Це пов'язано із загальною емоційною компетентністю, яка в людей 3 нарцистичним радикалом $є$ більш низькою, і недостатністю загальної диференційованості емоційної сфери [4; 7, с. 63].

3 метою дослідити психологічну структуру та прояви феномена нарцисизму в сучасній психологічній практиці, нами застосовано нарцистичний опитувальник особистості NPI-40 для діагностики рівня нарцистичних проявів і діагностики виду нарцистичних проявів, структурний тест Амона, який дає змогу оцінити психічне здоров'я людини, використовуючи 6 функцій особистості: агресію, тривогу, зовнішні обмеження, внутрішні обмеження, нарцисизм і сексуальність. Також нами проведено дослідження студентів-психологів за допомогою Торонтської алекситимічної шкали з метою виявлення здатності до диференціювання емоційних станів, здатності до їх вербалізації [4]. Шкала TAS спрямована на вивчення алекситимії як властивості особистості. У дослідженні взяли участь 48 студентів 3-4 курсів, спеціальності «психологія», переважно дівчата (44), середній вік - 20 років.

Визначення ступеня проявів нарцистичного радикалу залежно від рівня алекситимічних проявів за методикою NPI-40 представлені в таблиці 1 .

Таблиця 1

Середні значення показників рівня алекситимії та рівня нарцистичних проявів

\begin{tabular}{|c|c|c|}
\hline Методика/ рівень & Високий & Низький \\
\hline Рівень алекситимії & 72,4 & 54,5 \\
\hline Рівень нарцисизму & 17,4 & 12,88 \\
\hline
\end{tabular}

Отримані результати відображають наявний зв'язок між рівнем алекситимії та рівнем виразності нарцистичних проявів. Так, у групі з високими показниками алекситимії (середні показники - 72,4) показники за шкалою нарцисизму становили 17,4, що визначається як середні бали за шкалою (9-22). У групі з низькими показниками алекситимії середній бал 54,5 , показники нарцистичних проявів нижчі 12,88 , але також $є$ в середньому діапазоні.

Результати дослідження за методикою структурного тесту Амона представлені в таблиці 2.

Аналіз результатів свідчить про високі показники за такими шкалами, як тривога конструктивна, зовнішні обмеження деструктивні, зовнішні обмеження дефіцитарні; низькі показники за такими шкалами: тривога конструктивна. Також більшість респондентів використовують дефіцитарну агресію в серед- ніх значеннях за шкалою. Тривога переважає деструктивна та дефіцитарна, зовнішні та внутрішні обмеження переважають конструктивні. Нарцисизм переважає конструктивний і деструктивний. Аналізуючи показники за тестами NPI й тестом Амона, ми спостерігаємо зв'язок між рівнем нарцистичних проявів і підвищенням середніх показників у тесті Амона. Результати аналізу представлені в таблиці 3.

\section{Розподіл показників за шкалами}

Таблиця 2 тесту Амона у відсотках

\begin{tabular}{|c|c|c|c|}
\hline Шкала & \begin{tabular}{|c|} 
Високі \\
зна- \\
чення \\
$\%$ \\
\end{tabular} & $\begin{array}{c}\text { Середні } \\
\text { зна- } \\
\text { чення \% }\end{array}$ & \begin{tabular}{|c} 
Низькі \\
зна- \\
чення \\
$\%$ \\
\end{tabular} \\
\hline $\begin{array}{l}\text { Агресія конструк- } \\
\text { тивна }\end{array}$ & 13 & 53,3 & 33,3 \\
\hline $\begin{array}{l}\text { Агресія деструк- } \\
\text { тивна }\end{array}$ & 26,6 & 73,3 & 0 \\
\hline $\begin{array}{l}\text { Агресія дефіци- } \\
\text { тарна }\end{array}$ & 13 & 80 & 6,6 \\
\hline $\begin{array}{l}\text { Тривога конструк- } \\
\text { тивна }\end{array}$ & 33,3 & 33,3 & 33,3 \\
\hline $\begin{array}{l}\text { Тривога деструк- } \\
\text { тивна }\end{array}$ & 80 & 20 & 0 \\
\hline $\begin{array}{l}\text { Тривога дефіци- } \\
\text { тарна }\end{array}$ & 20 & 73,3 & 6,6 \\
\hline $\begin{array}{l}\text { Зовнішні обме- } \\
\text { ження конструк- } \\
\text { тивні }\end{array}$ & 0 & 80 & 20 \\
\hline $\begin{array}{l}\text { Зовнішні обме- } \\
\text { ження } \\
\text { деструктивні }\end{array}$ & 40 & 33,3 & 26,6 \\
\hline $\begin{array}{l}\text { Зовнішні обме- } \\
\text { ження дефіцитарні }\end{array}$ & 60 & 33,3 & 6,6 \\
\hline $\begin{array}{l}\text { Внутрішні обме- } \\
\text { ження конструк- } \\
\text { тивні }\end{array}$ & 0 & 73,3 & 26,6 \\
\hline $\begin{array}{l}\text { Внутрішні обме- } \\
\text { ження деструктивні }\end{array}$ & 26,6 & 53,3 & 13,3 \\
\hline $\begin{array}{l}\text { Внутрішні обме- } \\
\text { ження дефіцитарні }\end{array}$ & 33,3 & 66,6 & 0 \\
\hline $\begin{array}{l}\text { Нарцисизм кон- } \\
\text { структивний }\end{array}$ & 13,3 & 66,6 & 20 \\
\hline $\begin{array}{l}\text { Нарцисизм } \\
\text { деструктивний }\end{array}$ & 33,3 & 60 & 6 \\
\hline $\begin{array}{l}\text { Нарцисизм дефіци- } \\
\text { тарний }\end{array}$ & 33,3 & 46,6 & 20 \\
\hline $\begin{array}{l}\text { Сексуальність кон- } \\
\text { структивна }\end{array}$ & 20 & 66,6 & 13.3 \\
\hline $\begin{array}{l}\text { Сексуальність } \\
\text { деструктивна }\end{array}$ & 20 & 80 & 0 \\
\hline $\begin{array}{l}\text { Сексуальність дефі- } \\
\text { цитарна }\end{array}$ & 13,3 & 86,6 & 0 \\
\hline
\end{tabular}

Аналіз результатів свідчить про тенденцію зв'язку між рівнем нарцистичних проявів і підвищенням шкал за тестом Амона. Нами спостерігається тенденція збільшення середніх 
показників шкал і збільшення кількості шкал із підвищеними значеннями в тесті Амона в респондентів із високим рівнем нарцисизму. Це може свідчити про загальне напруження основних шкал, особливо шкали деструктивної тривоги, деструктивної агресії, деструктивних і дефіцитарних зовнішніх обмежень i деструктивного та дефіцитарного нарцисизму. Загальна тенденція до підвищення за означеними шкалами може бути проінтерпретована як регідність і легкість нарцистичної фрустрації та особливості від реагування тривоги й агресії.

\section{Середні значення показників рівня нарцистичних проявів і середніх показників у тесті Амона}

\begin{tabular}{|l|c|c|}
\hline \multicolumn{1}{|c|}{ Методика/рівень } & Високий & Низький \\
\hline Рівень нарцисизму NPI & 17,4 & 12,88 \\
\hline $\begin{array}{l}\text { Рівень середніх значень } \\
\text { за тестом Амона }\end{array}$ & 73,3 & 49,4 \\
\hline
\end{tabular}

Висновки $з$ проведеного дослідження. Отримані результати відображають наявний зв'язок між рівнем алекситимії та рівнем виразності нарцистичних проявів. Високий і середній рівні алекситимії поєднуються з підвищенням рівня нарцистичних проявів. Також високий рівень алекситимії пов'язаний із загальною напруженістю й корелює переважно з такими захистами, як проекція та регресія, що визначаються як найбільш незрілі. Низький рівень алекситимічних проявів корелює з використанням більш зрілого механізму раціоналізації. Установлено, що більш високі показники алекситимічних проявів корелюють із підвищенням рівня нарцистичних проявів у структурі особистості. Це пов'язано із загальною емоційною компетентністю, яка в людей із нарцистичним радикалом $€$ більш низькою, і недостатністю загальної диференційованості емоційної сфери. Рівень нарцистичних проявів знаходиться в діапазоні середніх значень і корелює з підвищенням напруження за шкалою в тесті Амона.

Отже, особистість із нарцистичним радикалом характеризується порушенням у структурі ідентичності. У нормі ідентичність постійно змінюється, тобто це динамічне функціональне утворення. Динамічність передбачає можливість змін і розвитку. Підвищення (напруження) за багатьма шкалами за результатами дослідження свідчить про рівень недиференційованої Я-концепції, що пов'язано з тим, що знання людини про себе будуть фрагментарними, уривчастими, суперечливими, на емоційному - у «зараженні» чужими емоціями, відсутності розуміння своїх почуттів і бажань. Отже, соціальний вплив і суспільні цінності є не єдиними факторами, що впливають на формування нарцистичної особистості, це є фундаментальною рисою, яка вибудовується в процесі ранніх стосунків і відіграє істотну роль у механізмі стосунків із собою та світом.

\section{ЛІТЕРАТУРА:}

1. Король Л.В. Причини формування нарцисичної особистості. Молодий вчений. 2017. № 3. С. 263-267. URL: http://nbuv.gov.ua/UJRN/molv_2017_3_63.

2. Малейчук Г.И., Олиферович Н.И. Особенности терапевтической работы с нарциссической травмой. Журнал практической психологии и психоанализа. 2009. № 3. URL: http://psyjournal.ru/ articles/osobennosti-terapevticheskoy-raboty-snarcissicheskoy-travmoy.

3. Шнейдер Л.Б. Личностная, гендерная и профессиональная идентичность: теория и методы диагностики. Москва : Московский психолого-социальный институт, 2007. 128 с.

4. Васильєва Г.В. Прояви алекситимії в структурі нарцистичної особистості. Теорія і практика сучасної психології. URL: https://doi.org/10.32840/2663-602 6.2019.6-1.22.

5. Мак-Вильямс Н. Психоаналитическая диагностика: Понимание структуры личности в клиническом процессе. Москва: Класс, 1998. 480 с.

6. Lysenkova I.P. Correction-Developing Environment as a Means of Emotional Development of Children with Cognitive Impairment. The Norwegian Journal of Development of the International Science. 2018. № 20. Vol. 2. P. 67-69.

7. Искусных А.Ю., Попова Л.И. Алекситимия у студентов. Распространенность, причины, последствия. Личность, семья и общество: вопросы педагогики и психологии : сборник статей по матер. Междунар. науч.-практ. конф. Новосибирск : СибАК, 2016. № 9 (66). С. 61-65. 